\title{
MORPHOLOGY AND SYNTAX IN HOLES AND SCRATCHES: The LATEST Stage OF KUGYol RESEARCH
}

\author{
LEE Yong \\ Korea Foundation \& University of Ljubljana \\ leeyonghu@hotmail.com
}

\begin{abstract}
The first part of this article reviews the differences between the Chinese, Korean and Japanese languages, and explains the importance of Buddhist texts in the history of these languages, especially in the development of written languages in Korea and Japan. The kugyol tradition (a convention for adding Korean grammatical markers at appropriate places to aid the reading of originally Chinese texts) is then explained with concrete examples in three parts: eumdok kugyol (transliteration kugyol), seokdok kugyol (translation kugyol), and jeomto seokdok-kugyol (traslation kugyol with point marks). The latest developments in kugyol research were seen in the $21^{\text {st }}$ century, after the discovery of Yugasijiron in the year 2000, including the detailed point maps. Some questions concerning the jeomto seokdok-kugyol are still open.
\end{abstract}

\section{Keywords}

interpretation of Buddhist texts, Korean, classic Chinese, eumdok kugyol, seokdok kugyol, jeomto kugyol, jeomto

\section{Izvleček}

Prvi del članka obravnava razlike med kitajskim, korejskim in japonskim jezikom ter poudarja pomembnost budističnih besedil v zgodovini omenjenih jezikov, zlasti pri oblikovanju pisnih jezikov v Koreji in na Japonskem. V glavnem delu razlaga tradicijo kugyol (konvencijo, po kateri se dodajajo slovnični znaki na ustreznih mestih kot pomoč pri branju prvotno kitajskih besedil) z dejanskimi primeri $\mathrm{v}$ treh delih: eumdok kugyol (transliteracijski kugyol), seokdok kugyol (prevajalski kugyol) in jeomto seokdok-kugyol (prevajalski kugyol z dodajanjem pik). Najnovejše v raziskavi kugyol tradicije je bilo narejeno v tem stoletju, po odkritju Yugasijiron v letu 2000, npr. Podrobna porazdelitev pik idr. Nekatera vprašanja v zvezi z jeomto seokdokkugyol ostajajo odprta.

\section{Ključne besede}

interpretacija budističnih besedil, korejščina, klasična kitajščina, eumdok kugyol, seokdok kugyol, jeomto kugyol, jeomto 


\section{Introduction (Historical background)}

At present, each of the three countries of East Asia, China, Korea and Japan, has its own independent writing system. Before the 7th century however, the Korean and Japanese peoples, though they possessed their own languages, had no writing systems of their own. Later, they developed their own writing systems, based on Chinese characters. This paper is related to the history of the development of these writing systems.

The languages of these three peoples differ. Typologically speaking, Chinese is an SVO language but Korean and Japanese are SOV languages. In addition, Korean and Japanese are different in many respects, and there exists no concrete theory to prove that they are related in the sense of European comparative linguistics.

In general, literature written in Korea falls into three categories: 1) works written in the early transcription systems, 2) those written in hangul, and 3) those written in Chinese. (cf. Encyclopaedia Britannica, Academic Edition) In this article, we will concentrate on the first category of Korean writings of which the content is typically Buddhist teachings from 8th century on.

Some Buddhist texts are common to both Korean and Japanese. Korean and Japanese scholars from around the 6th century and later were eager to learn from China in order to unite their peoples. Buddhism was one of the strongest means available. However, the original Buddhist teachings written in Chinese needed translation and interpretation into languages which were otherwise spoken among people but had no writing system of their own. It means that the interpretation of Buddhism coincided with the formation of the written languages of these peoples.

The understanding of Korean kugyol tradition may demonstrate how a nation may develop devices in order to understand foreign data when lacking their own writing system. These devices are characterized by additions of phonetic, semantic and syntactic markers made by brush and ink, as well as holes and scratches made by a stylus on paper.

\section{Modern writing systems of China, Korea and Japan}

Firstly, we need to examine simple sentences in today's Chinese, Korean and Japanese to demonstrate how they differ, especially syntactically. See example sentences below:

$\begin{array}{lll}\text { (1) Chinese: } & \text { 我 愛 } & \text { 你 } \\ & \text { wə ai } & \text { ni } \\ & \text { I to love } & \text { you } \\ & \text { "I love you." } & \end{array}$


$\begin{array}{llllll}\text { (2) Korean: } & \text { 나 는 } & \text { 너 } & \text { 를 } & \text { 사랑하 } & \text { 다. } \\ & \mathrm{Na} \text { nin } & \text { nə } & \text { ríl } & \text { sarangha } & \text { nda } \\ & \text { I } \text { [topic] you } & \text { [acc] } & \text { to love } & \text { [ending marker] } \\ & \text { "I love you." }\end{array}$

(3) Japanese: 私 は あなたを愛します。

Watasi wa anata o aisi masu

I [topic] you [acc] to love [ending marker]

"I love you."

As we can see, Korean and Japanese sentences are rather similar in word order, SOV, and the functions of particles (or postpositions). On the other hand, Chinese has no such particles, and the word order is SVO.

As for the letters and characters, while the Chinese have used logographic characters since around 3000 years B.C., the Japanese have retained some logographic Chinese characters which are used today in combination with syllabic characters called kana. This Japanese system has developed from the 8th century on and is generally still in use. The Koreans today use hangul, which has developed since the 15th century, a phonemic alphabet organized into syllabic blocks (cf. example sentence (2) above and Figure 1 below).

\begin{tabular}{|c|c|c|c|}
\hline $\begin{array}{c}\text { Letters } \\
\text { (consonants) }\end{array}$ & sound value & $\begin{array}{c}\text { letters } \\
\text { (vowel) }\end{array}$ & sound value \\
\hline$\neg$ & {$[\mathrm{g}, \mathrm{k}]$} & r & [a] \\
\hline ᄂ & {$[\mathrm{n}]$} & F & [ya] \\
\hline ᄃ & {$[\mathrm{d}, \mathrm{t}]$} & -1 & [ə] \\
\hline ᄅ & {$[\mathrm{r}, 1]$} & 三 & [уә] \\
\hline ロ & {$[\mathrm{m}]$} & 工 & {$[0]$} \\
\hline 甘 & {$[\mathrm{b}, \mathrm{p}]$} & 피 & [yo] \\
\hline 入 & [s] & T & {$[\mathrm{u}]$} \\
\hline 0 & {$[\mathrm{y}]$} & $\pi$ & [yu] \\
\hline 下 & {$[\mathrm{dz} / \mathrm{t}]$} & 一 & {$[\grave{i}]$} \\
\hline 天 & {$\left[c^{h}\right]$} & 1 & [i] \\
\hline$\Rightarrow$ & {$\left[\mathrm{k}^{\mathrm{h}}\right]$} & & \\
\hline$E$ & {$\left[\mathrm{t}^{\mathrm{h}}\right]$} & & \\
\hline 프 & {$\left[\mathrm{p}^{\mathrm{h}}\right]$} & & \\
\hline $\bar{\delta}$ & {$[\mathrm{h}]$} & & \\
\hline
\end{tabular}

Figure 1 hangul alphabet 
Each block of hangul letters consists of at least two of the 24 hangul letters (jamo 字母), with at least one each of the 14 consonants and 10 vowels. These syllabic blocks can be written horizontally from left to right, as well as vertically from top to bottom in columns from right to left.

But before the development of this hangul system, the Koreans started writing down their language around the 5th century by using Chinese characters. Then they developed their own transcription systems, idu ${ }^{1}$, hyangchal ${ }^{2}$ and kugyol. The present article examines the kugyol system.

\section{Kugyol (口訣)}

Kugyol has two kinds of meaning. One refers to the letters which are used in kugyol texts. The second refers to texts with kugyol letters. In the former case, kugyol were the Korean markers added to purely Chinese text (Chung, 2003). In Korea, when reading a text written in literary Chinese, there was a convention for adding Korean grammatical elements at appropriate places to aid the reading of the text. These added elements were called kugyol. In other words, kugyol letters were the devices used to read and understand Chinese texts (Kim, 2001). Usually, a kugyol letter is made by taking a part of an original Chinese character and it is then slightly changed in form to form a kugyol marker : ex. I , 1, ‥ The principle of the formation of kugyol letters

\begin{tabular}{|c|c|c|c|c|c|c|c|c|c|c|c|c|}
\hline $\begin{array}{l}\text { 去 } \\
\Rightarrow\end{array}$ & $\begin{array}{c}\text { 在 } \\
+\end{array}$ & 古 & $\begin{array}{l}\text { 果 } \\
\text { 人 }\end{array}$ & $\begin{array}{l}\text { 示 } \\
\text { 小 }\end{array}$ & $\begin{array}{l}\text { 這 } \\
\text { 己ृ }\end{array}$ & $\begin{array}{l}\text { 只 } \\
\text { 品 }\end{array}$ & $\begin{array}{l}77 \\
73\end{array}$ & $\begin{array}{l}\text { 奴 } \\
\text { x }\end{array}$ & $\begin{array}{c}\text { 臥 } \\
+\end{array}$ & $\begin{array}{l}\mathbb{r}_{0} \\
E\end{array}$ & $\begin{array}{c}\text { 㩊 } \\
7\end{array}$ & \\
\hline 多 & 丁 & 刀 & 知 & 大 & 冬 & 矣 & 羅 & 以 & 䨔 & 利 & p & \\
\hline 1 & $T$ & $D$ & 先 & の & x & $A$ & $\infty$ & $\cdots$ & 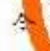 & F & $\rho$ & \\
\hline 乙 & ' & 弥 & 毛 & 音 & 邑 & 火 & 沙 & 示 & 吨 & 泉 & 亦 & \\
\hline ᄂ & $\tau$ & 5 & 毛 & A7/ 호 & $e$ & 火 & ; & $=$ & $t$ & 3 & ; & \\
\hline 良 & 乎 & 于 & 衣 & 是 & + & 齊 & 下 & 平 & 乎 & 务 & 為 & 中 \\
\hline 2 & 3 & $f$ & ; & II & $k$ & $\%$ & $T$ & 1 & $\Rightarrow$ & 古 & " & + \\
\hline
\end{tabular}

closely resembles the formation of kana in Japanese. (See Figure 2 and Figure 3.)

Figure 2 Seokdok-kugyol letters and original Chinese characters

\footnotetext{
${ }^{1} I d u$ is an archaic writing system that represents the Korean language by using hanja (Chinese characters). The term idu is used in two senses. It may refer to various systems of representing Korean phonology through Chinese characters. In this sense it includes hyangchal and kugyol writing. In the narrower sense it refers solely to the system which was used in official documents.

${ }^{2}$ Hyangchal is the most highly developed form of Korean transcription in Chinese characters. It can be found in the vernacular poetry known as hangga.
} 
Figure 3 Kana letters and original

Chinese characters

(http://en.wikipedia.org/wiki/Kana)

The kugyol letters were used to denote grammatical elements and inserted into originally Chinese texts for easier interpretation among Koreans. There are largely two kinds of kugyol texts in Korea. One is eumdok kugyol (=transliteration kugyol), the other is seokdok kugyol (=translation kugyol); the latter are older than the former. The oldest text with kugyol interpretation is Hwaeommuneuiyogyeol (華嚴文義 要 訣), the annotation of the Hwaeomkyeong ${ }^{3}$. The Korean original of Hwaeommuneuiyogyeol is lost but a copy has existed in Japan since the 8th century.

There exist many Buddhist sutras in Korea, all of them with kugyol interpretation using kugyol letters. Of these, five seokdok-kugyol texts are especially important in kugyol study. ${ }^{4}$ One of the representative texts with kugyol is Kuemkwang myeonggyeong (金光明経). ${ }^{5}$ Kuemkwang-myeonggyeong includes seokdok and jeomto kugyol. We will explain this point in the next chapter.

${ }^{3}$ Hwaeumkyeong (華嚴經, The Avatamsaka Sūtra) is one of the most influential Mahayana Sutras of East Asian Buddhism. The title is rendered in English as Flower Garland Sutra, Flower Adornment Sutra, or Flower Ornament Scripture. The Avatamsaka Sütra describes a cosmos of infinite realms upon realms, mutually containing one other.

${ }^{4}$ These are five seokdok kugyol texts.

1) Taebanggwangbul-hwaeomkyeongso (大方廣佛華嚴經口), vol. 35: Xylographic book, Presumed to be a 12th century publication.

2) Taebanggwangbul-hwaeomkyong (大方廣佛華嚴經), vol. 14. Xylographic book. Presumed to be a late 12 th-early 13 th century publication.

3) Keumgwangmyeonggyeong (金光明經), vol. 3. Xylographic book. Presumed to be a 13th century publication, and considered to have belonged to the same category as Yugasajiron. The first and the last two pages of the volume are assumed to have been written by a different writer from the rest of the text.

4) Kuyoek-inwanggyong (舊譯仁王經) vol. 1. Xylographic book. Only 5 page remain. 25 lines per page, and 17 characters per line. Presumed to have been written in the 13 th century.

5) Yugasajiron (瑜伽師地論Yogācārabhūmi-śāstra), also known as Discourse on the Stages of Yogic Practice is the encyclopaedic and definitive text of the Yogācāra school of Buddhism. It is thought to have been composed in India between 300 and 350 CE. Vol. 20. Xylographic book. This book shows the latest linguistic characteristics among the existing Seokdok-kugyol material.

${ }^{5}$ Kuemkwangmyeonggyeong (金光明經, The Suvarnaprabhāsa-sūtra) is a Buddhist text of the Mahayana branch of Buddhism. Its first reading as a court ceremony was around 660 AD, when the Tang Dynasty of China and Silla (新羅) of Korea had defeated Baekche (百濟) of Korea and were threatening Japan. 
In the following sections, we will explain exactly how the system of kugyol interpretation is organized.

\subsection{Eumdok kugyol (=Transliteration kugyol, 音讀口訣)}

Let us look at an example of eumdok kugyol from the Analects of Confucius. ${ }^{6}$ (See Figure 4)

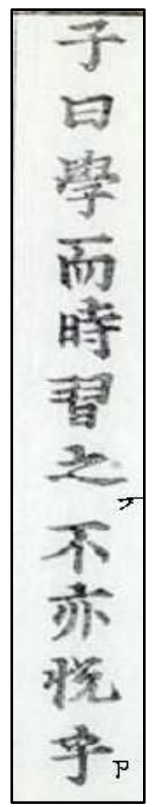

Here we can see two kugyol letters. One is $\tau$ and the other is $P$. The former has the meaning 'if' in English and the latter has the function of interrogative marker. The main characteristic of the eumdok-kugyol is the position of kugyol letters at the end of each phrase or sentence. As we see, the main functions of eumdok-kugyol letters are case markers and sentence ending markers.

The eumdok-kygyol letters were used from the end of the Goryo dynasty (13th century) to the Chosun dynasty (14-20th century). These eumdok-kugyol texts were studied only by a handful of people.

Figure 4 An example from the Analects

(4a) classical Chinese:

學而時之習之不亦悅乎 to learn and time, often to learn it not too glad [interrogative] "Is it not pleasant to learn with constant perseverence and application?"

(4b) with eumdok-kugyol :

學而時之習之不亦悦乎p

to learn and time, often to learn [if, 면[myen]] not too glad [interrogative, 아[a])] "Is it not pleasant to learn with constant perseverence and application?"

(4c) Korean translation:

배우 고 때때로 익히 면 또한 기쁘지 아니 한가?

to learn and time, often to learn if too glad not [interrogative] "Is it not pleasant to learn with constant preseverence and application?"

\footnotetext{
${ }^{6}$ Noneo 論語 (Lún Yŭ, English: Analects), also known as the Analects of Confucius, are considered a record of the words and acts of the central Chinese thinker and philosopher Confucius and his disciples, as well as the discussions they held. Written during the Spring and Autumn Period through the Warring States Period (ca. 475 BCE - 221 BCE).
} 


\subsection{Seokdok-kugyol (=Translation kugyol, 釋讀口訣)}

The discovery of Kuyeok-inwangkyeong (舊譯仁王經) (See Figure 5, footnote 4, number 4) which is one of seokdok-kugyol texts changed the situation in the study of kugyol. This text was found in the temple Chungcheongnamdo seosan munsu (忠淸南 道瑞山文殊寺) in 1973. Scholars saw that the kugyol in this text was more complicated and detailed than eumdok kugyol. The seokdok-kugyol system has the following characteristics:

- Kugyol letters are placed not only on the right, but also on the left side of the original rows of Chinese text.

- There are some purely syntactic markers which are never pronounced (and they mean "do read", "skip reading", "return and read the skipped part now" etc.)

- Seokdok-kugyol markers are introduced to point out the meaning of the original Chinese character and instruct for phonetically Korean reading.

- Additional markers are introduced for modality, aspect etc. to be read in Korean.

Below is an example of Chinese classics read in Korean with kugyol devices. To read kugyol texts, we need to know the following rules:

- kugyol letters on the right side must be read in the first phase,

- kugyol letters on the left side must be skipped in the first phase,

- the reversal mark ( ' ) is the key of reading and means "go back from this point to the kugyol character on the left side."

Therefore, one can read from the first purple line to the second purple line in Figure 5 as below: 


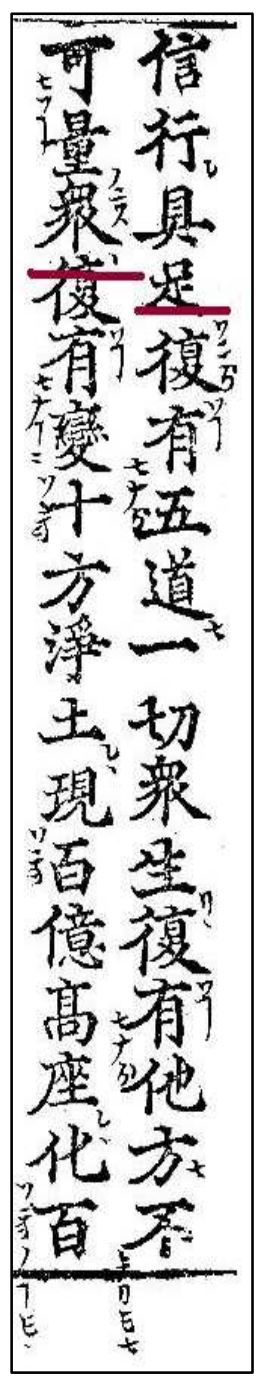

Figure 5 kuyeok-inwangkyeong

(5a) original text ([ ] marks kugyol letters on the left side):

有 $[t+5]$ to exist, to have (part of verb+perf.+conj.)

五 five

道 $t \quad$ way (gen.)

一切 entire, every

衆生川、 living things (subj.)

"all living things of five directions exist"

(5b) in Korean word order:

五道七 [s] Five way (gen.)

一切 entire, every

衆生川 [i] living things (subj.)

有 $七$ 广 [s-kyə-myə] to exist, to have (part of verb+perf.+conj.)

"all living things of five directions exist"

(5c) reconstruction:

五道七

Five way (gen.)

一切

entire, every

衆生川 living things (subj.)

有七ナろ to exist, to have (part of verb+perf.+conj.)

"all living things of five directions exist"

(5d) translation in modern Korean:

五道入

一切

Five way (gen.)

衆生이

entire, every

잇겨며

living things (subj.)

"all living things of five directions exist"

When we read this part, we will first meet 有 $[t+3]$. In 有 $[t+3],[]$ represents the kugyol on the left side, so we do not need to read this in the first phase of reading. The first kugyol which we read is $t$. And then we meet $"$ and. Here is a reverse marker. When we meet this marker, we should go back to 有 [ $七$ ` ]. We can see the result in (5b). (5a) is the arrangement in Chinese word order but (5b) is the arrangement in Korean word order. If we just follow indications by kugyol devices, we can translate Chinese classics into Korean.

We can read the rest of the text with the same method.

< Kuyeokinwangkyeong; 02:01> 
(6a) original text ([ ] marks kugyol letters on the left side):

復, 1

有 $[七+3]$

五

道

一切

衆生川、

復り 1

有 $[$ 十

他方七

不 $[$ 矢川

可[七” 1、]

量, 市、

衆、
Also(part of adv.)

to exist, to have (part of verb+perf.+conj.)

five

way (gen.)

entire, every

living things (subj.)

Also(part of adv.)

to exist, to have (part of verb+perf.+conj.)

other directions (gen.)

not (part of neg.+noun+gen.)

can (part of adj.+suf.+mod.)

to count (suf.+dev.)

living things

"Also there are all living things of five directions and also in other directions there are uncountable living things"

(6b) in Korean word order ( \{\} marks a character not to be pronounced in $\{$ 可 $\})$ :
復 ’ $7[\mathrm{~h} \Lambda \mathrm{n}]$
Also (part of adv.)
五道七 [s]
five way (gen.)
一切
entire, every
衆生川 [i]
living things (subj.)
有七ナ3 [s-kyə-myə]
to exist, to have (part of verb+perf.+conj.)
復” $1[\mathrm{~h} \wedge \mathrm{n}]$
Also (part of adv.)
他方七 [s]
other directions (gen.)
量,
to count (suf.+dev.)
\{可\}七” 1 [homs-hın]
can (part of adj.+suf.+mod)
不知 $ヒ t[$ an-dji-n $\Lambda$ s]
衆
not (part of neg.+noun+gen.)
有 [ s-kyə-myə]
living things

"Also there are all living things of five directions and also in other directions there are uncountable living things"

(6c) reconstruction:

$\begin{array}{ll}\text { 소흔 } & \text { (part of adv.) } \\ \text { 五道人 } & \text { five way (gen.) } \\ \text { 一切 } & \text { entire, every } \\ \text { 衆生 | } \mid & \text { living things (subj.) } \\ \text { 잇겨며 } & \text { to exist, to have (part of verb+perf.+conj.) } \\ \text { 소흔 } & \text { Also (part of adv.) } \\ \text { 他方人 } & \text { other directions (gen.) } \\ \text { 量홈짓흔 } & \text { to count (suf.+dev.) can (part of adj.+suf.+mod) } \\ \text { 안디이 } & \text { not (part of neg.+noun+gen.) } \\ \text { 衆 } & \text { living things } \\ \text { 잇겨며 } & \text { to exist, to have (part of verb+perf.+conj.) }\end{array}$

"Also there are all living things of five directions and also in other directions there are uncountable living things" 
(6d) translation in modern Korean:

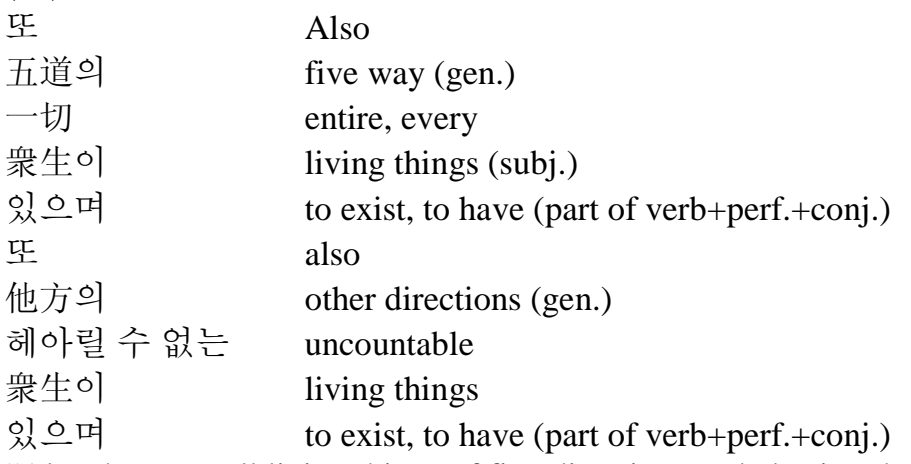

"Also there are all living things of five directions and also in other directions there are uncountable living things"

\subsection{Jeomto Seokdok-kugyol（點吐釋讀口訣）}

This kind of marking was first discovered in $2000^{7}$ in the text Yugasajiron (瑜伽 師地論, cf. footnote 4, number 5). We have seen that different kugyol letters mark various syntactic, morphological and phonetic help for interpretation and translation of the original text. Jeomto, which means "point marks to translate into Korean" and are actually holes and scratches on paper, play the same role as that of the kugyol letters. Each jeomto corresponds to one kugyol letter or a group of kugyol letters (Chang, 2002).

Because jeomto is marked with a very sharp pointed pen which is called a stylus (Figure 6), it is difficult to find jeomto marks for us without special instruments (Kobayashi 2002). Scopes are used as special instruments to light texts (Figures 7a, 7b, $7 \mathrm{c})$.

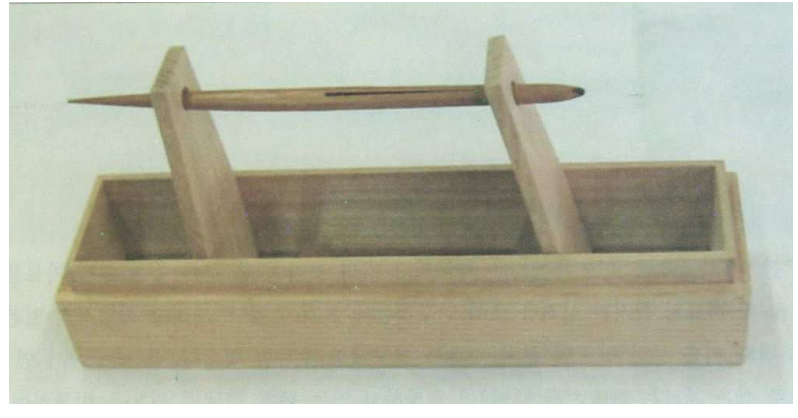

Figure 6 Stylus (reconstruction / Kobayashi Yoshinori)

\footnotetext{
${ }^{7}$ In the year 2000, Kobayashi, a researcher of Japanese kunten texts (see also footnote 10), found additional markers which were not made by brush and ink, but made by the use of a stylus in Yugasajiron vol 5,8 .
} 
Figure 7a Scope instruments

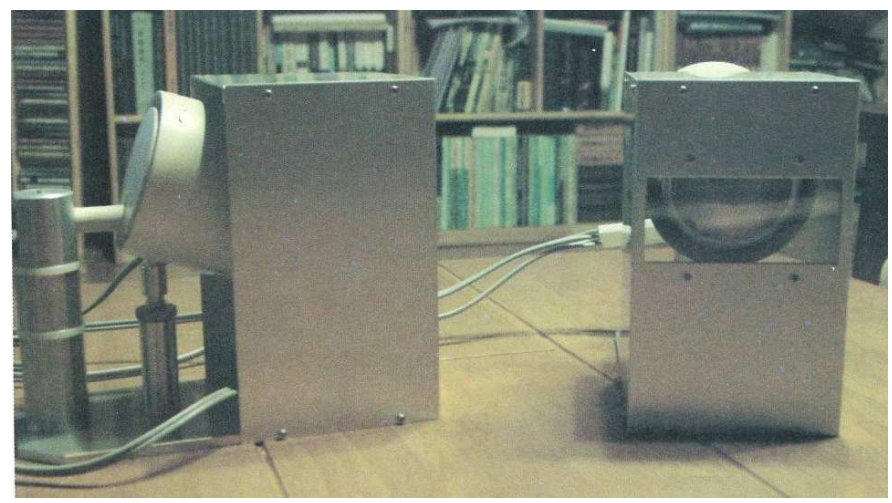

Figure 7b Inspecting a text with scopes on the desk

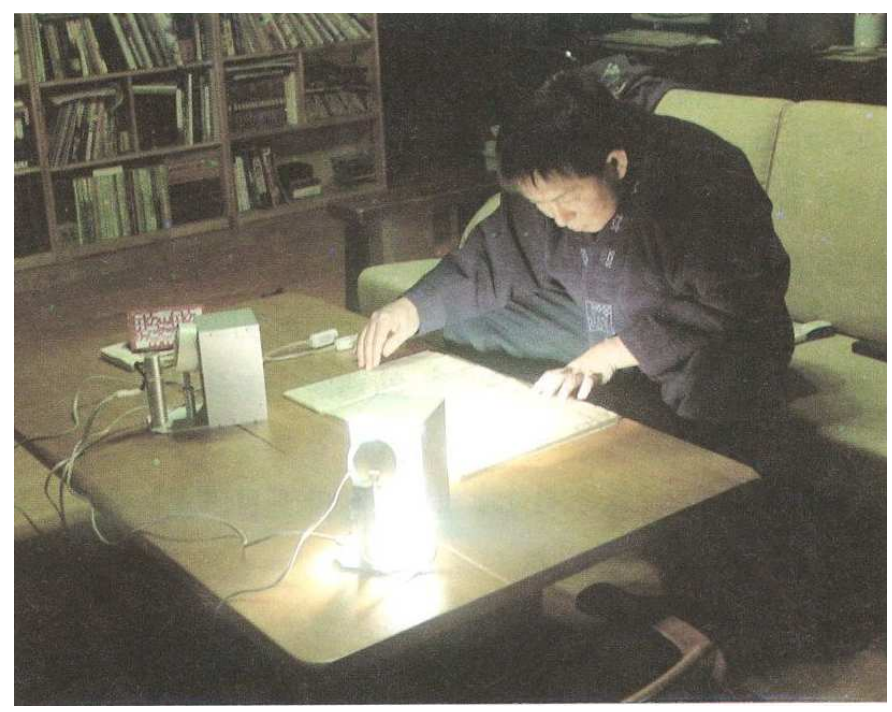

Figure 7c Enlarged text

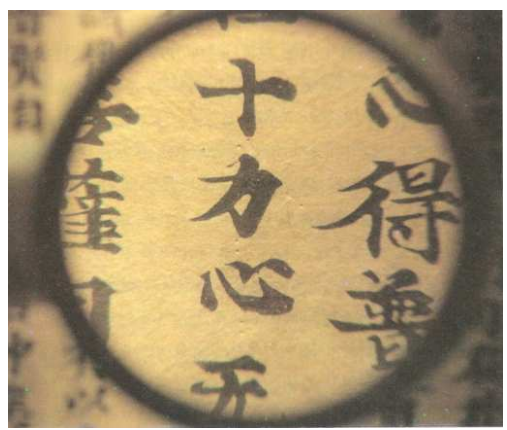

When Korean read Chinese characters, they made small holes and scratches with a stylus on paper to read the text more fluently but with strict rules. In the following photos, we can find small holes and scratches. 


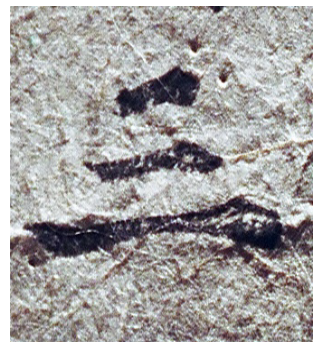

三 a

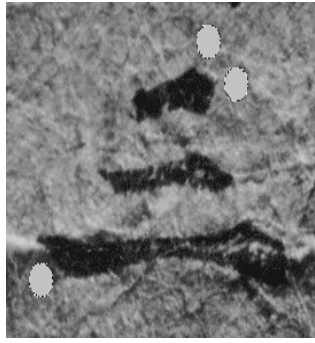

三 b

<Yugasajiron 08 01:06:08>

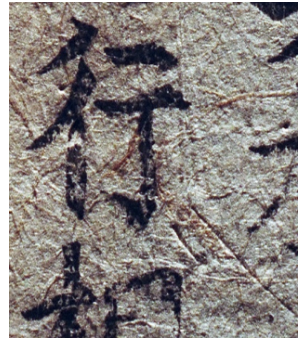

行 $a$

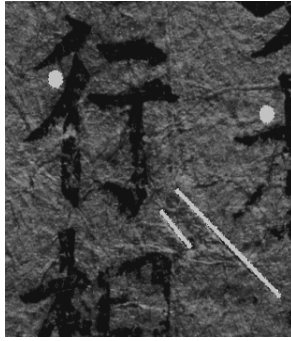

行 b

$<$ Yugasajiron 08 01:15:12>

Figure 8 (a) and (b) (characters 三、行 with points and lines) (Lee, 2004)

In Figure 8, $a$ is the original picture and $b$ is a painted picture. If somebody cannot see holes or scratches, he can get a hint from picture $b$. We can see points in a, 三, and points and lines in $b$, 行.

Of seokdok-kugyol texts, Keumkwangmyeongkyeong (cf. footnote 4, number 3) is the only text which contains both kugyol letters and jeomto marks. So we can compare kugyol letters and jeomto by observing the Kuemkwangmyeongkyeong text.
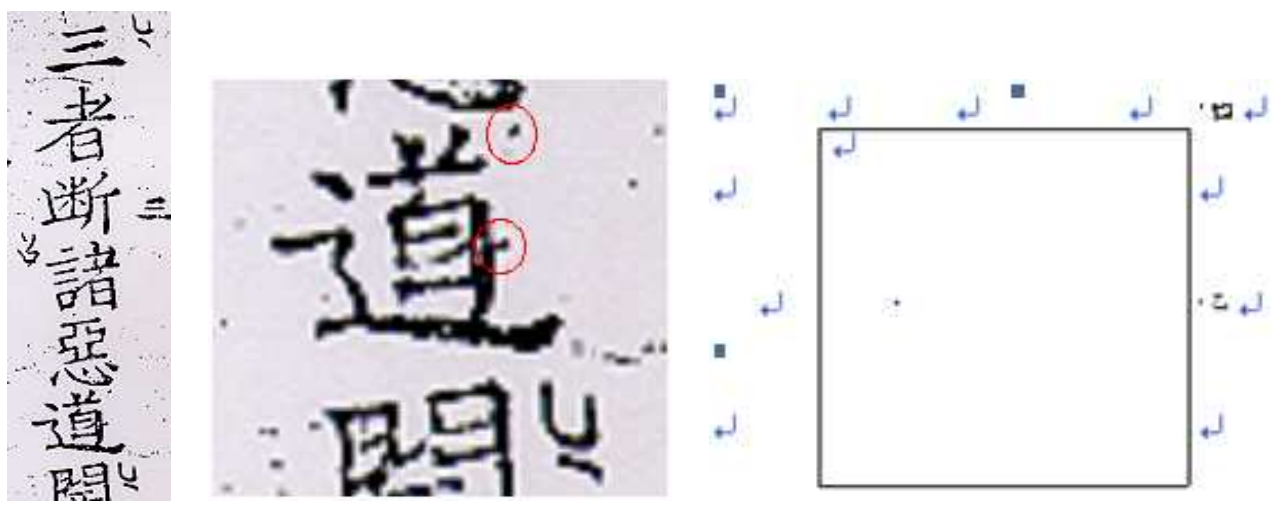

Figure 9 The positions of kugyol points

As shown in Figure 9, the jeomto seokdok-kugyol markers in small dots correspond to the markers made by kugyol letters. This may mean that the help for interpretation of the original text is doubly marked in Keumkwangmyeongkyeong. If we concentrate on the character 道, we can find two dots. Two dots are located on the right side of 道. One is in the upper position, another in the central position. These dots correspond to each $\square$ and $乙$. $\square$ is a coordinating conjunctive marker, and $乙$ is an objective marker.

After some research, all possible positions of jeomto points which correspond to various syntactic, morphological and phonetic markers were mapped as in Figure 10: 


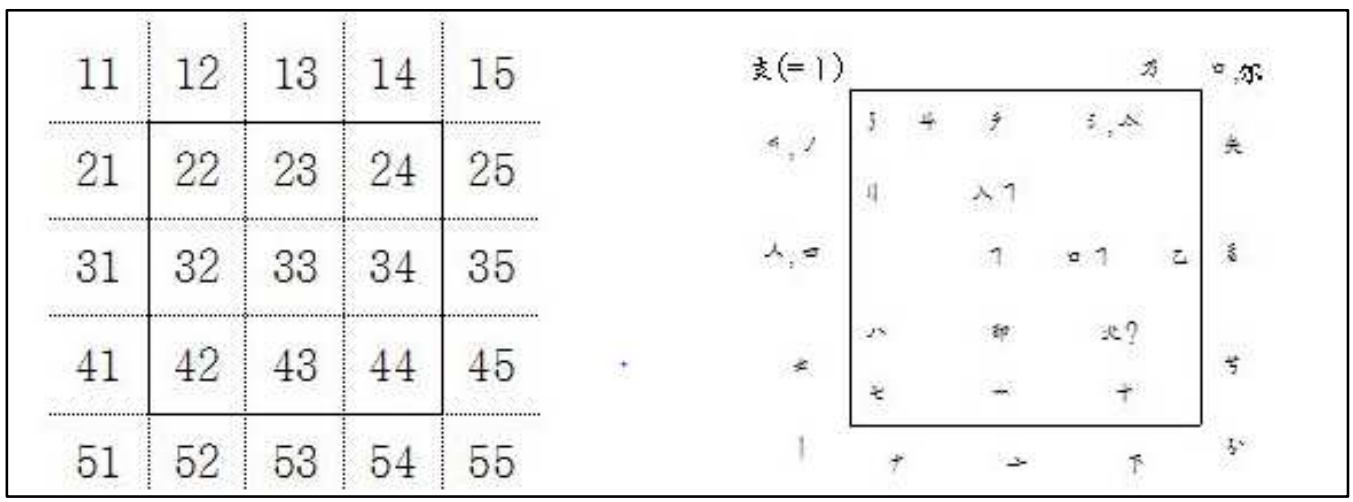

Figure 10 The point map of Yugasajiron (Chang, 2002)

By looking at existing texts closely, the researchers found out that approximately 15 additional texts were marked by holes and scratches. ${ }^{8}$

\section{The latest findings and open questions}

In this section we will examine Hwaeommuneuiyogyeol 華厳文義要訣 which is presumed to be a text from the Silla dynasty (57 BE - 935 AD). Before examining Hwaeommuneuiyogyeol, we need to know Tōdaiji Fujumonkō (東大寺諷誦文稿, Tōdai Temple Buddhist Prayers Manuscript).

Tōdaiji Fujumonkō is an early 9th century Buddhist text and is best known as a valuable resource for Japanese historical linguistics as well as Buddhist history. It was composed some time between 796-830. The manuscript was designated as a National Treasure of Japan in 1938, but destroyed in 1945 in fires resulting from the war. Only reproductions remain. Tōdaiji Fujumonkō is primarily important as a resource for Early Middle Japanese. It is the oldest example of text written in kanji (Chinese characters) with katakana (phonetic alphabet) annotations. In addition, it exhibits many elements of Old Japanese grammar and vocabulary, as well as maintaining the phonetic distinction between $/ \mathrm{ko} 1 /$ and $/ \mathrm{ko} 2 /$. It also contains accounts in several dialects. (cf. http://en.wikipedia.org/wiki/ Tōdaiji_Fujumonk)

${ }^{8}$ Jinbon Hwaeumkyeong (晋本華嚴經) vol. 20: The late 9 AD- the early 10 AD, Seomam koseo museum. Yugasajinron (瑜伽師地論) vol. 3: The first half of 11 AD, Horim museum.

Yugasajinron (瑜伽師地論) vol. 5, 8: The first half of 11 AD, Seomam koseo museum.

Jubon Hwaeum kyeong (周本華嚴經) vol. 6, 22, 36, 57: The late 11 BC or The early 12 BC, Seomam koseo museum.

Jubon Hwaeum kyeong (周本華嚴經) vol. 31, 34: The late 11 BC- the early 12BC, Horim museum. 


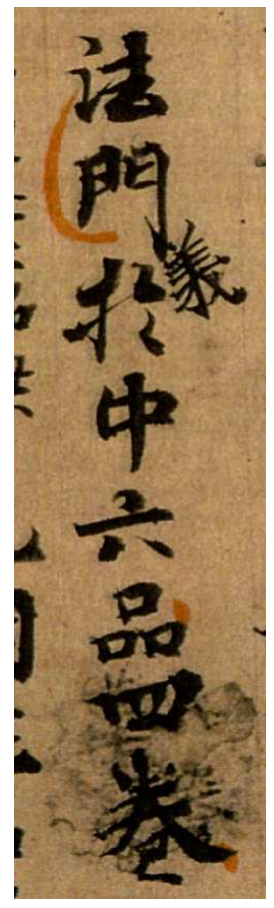

This important text was actually written on the reverse of an older text, Hwaeommuneuiyogyeol (written by a Silla monk, $P$ 'yonwon) in the early 8th century. The latter is of interest in the context of jeomto kugyol. Hwaeommuneuiyogyeol has points and lines made by brush (Kobayashi, 2002). The jeomto points and lines on this text must have been made in late 8th century. Since a very similar method of interpretation and translation of Buddhist texts exists in Japan and in Japanese (the kunten system ${ }^{9}$ ), scholars did not know in which country the marks were made, i.e. in Korea or in Japan, or at which time the text was imported to Japan from the Korean peninsula. The scholars are also very curious about the identity of the writer, P'yonwon and if he was Korean or Japanese.

But Kobayashi (2002) insists that the points and lines in the text Hwaeummuneuiyogyeol are to be read in Korean. How this text can be read in Korean is shown below.

Figure 11 Hwaeom muneui yogyeol

Hwaeommuneuiyogyeol text:

(7a) original text with jeomto:

六品 $[23(\bullet)]$ 四卷 $[33(\bullet)]$

six articles (top.) four volumes (declarative)

"Six articles ard (written) in four volumes"

(7b) Korean interpretation with kugyol letters:

六品 7 四卷(川)।

six articles (top.) four volumes (copula) (declarative)

"Six articles ard (written) in four volumes"

(7c) reconstruction:

六品은

四卷이다

six articles (top.) four volumes (copula) (declarative)

"Six articles ard (written) in four volumes"

(7d) translation in modern Korean:

六品은 四卷이다

six articles (top.) four volumes (copula) (declarative)

"Six articles ard (written) in four volumes"

The point in the character 品, made by red ink, represents a subject (or topic) marker. But this text can be read in Japanese, too. The important point in this

\footnotetext{
${ }^{9}$ Kunten: Guiding markers for rendering Chinese classics into Japanese.
} 
discussion is that the syntax markers (for example, the subject marker) are common to both languages and in reading it may be pronounced in Korean or Japanese.

Because Japanese syntax is similar to Korean syntax in many respects, it is difficult to decide if it is a Korean text or a Japanese text.

However, Kobayashi (2002) insists that Hwaeommuneuiyogyeol is a Korean text because:

- Its point map is similar to the point map of the 12 th century Korean Hwaeomkyong. (Figure 12)

- We can find subject/topic markers in Hwaeommuneuiyogyeol, but there are no subject markers in Japanese texts before 8th century.

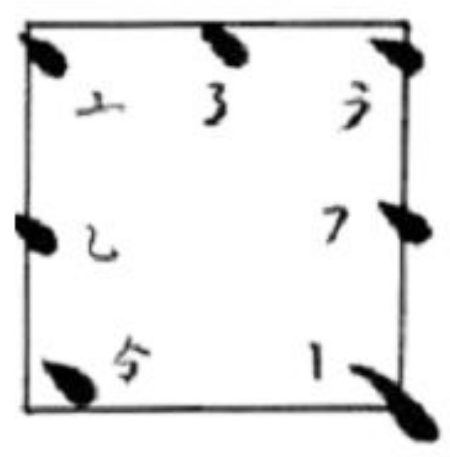

(Kim 2003)

Hwaeommuneuiyogyeol

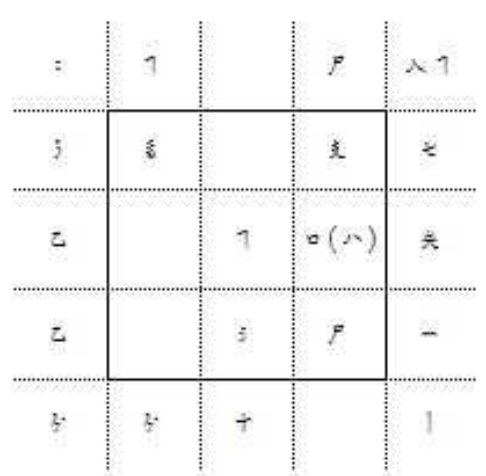

(Park 2006)

Hwaeomkyeong

Figure 12 Point map of Hwaeommuneuiyogyeol and Hwaeomkyeong

Since Korean and Japanese are similar to each other, the following questions still remain open:

- Who made these points and lines and when?

- In what language did they read these texts?

\section{References}

Chang, K. (2002). Jeomtoseokdokkugyol Jaryo-e Giipdoen Kugyeolja-wa Daeeung Kugyoljeom-e Daehayeo - Yugasajiron Kwon 5, 8eul Daesangeuro (A Study on Correspondences between Kugyol Characters and Kugyol Points which are recorded in Yugasajiron vol. 5, 8 ), Kugyol Studies, 9, 205-225.

Chang, K.(2003). On the 'indicator line' used in the Yuqie shidi lun(瑜伽師地論)'s pointattached seokdokkugyol, Kugyol Studies, 11, 189-209. 
Chung, J. (1999). Sǒkdokkugyǒl in the Koryǒ Period, Seoul Journal of Korean Studies, 12, Institute of korean studies, Seoul national university.

Chung, J. (2001). On Jinbon Hyayangjing(育本 華嚴經) vol. 20 at Sung-am Archives of Classical Literature, Kugyol Studies, 7, 33-56.

Chung, J. et al. (2003). Hanguk Gakpil Buhokugyol Jaryo-wa Ilbon Hunjeom Jaryo Yeongu Hwaeomgyeong Jaryoreul Jungsimeuro- (A Study on Korean Gakpil Buhokugyol Texts and Japanese Kunten Texts - focused on Hwaeomgyeong Texts-. Seoul, Korea: Taehaksa.

Kim, Y. (2001). Decoding methods on the Dots and Lines in Yuga-sagi-lon, Kugyol Studies, 7 , 57-77.

Kim Y. (2003). A linguistic study of Hwa.eom.mun.eui.yo.gyeol, Kugyol Studies 10, 47-78.

Kim, Y. (2004). A Korean linguisitic study of Pan-bi-lyang-lon, Kugyol Studies, 12, 81-97.

Ko, J. (2004). A review of the study on Kugyol, Kugyol Studies, 12, 5-44.

Ko, Y. (1998). Seokdok Kugyol-ui Gugeosajeok Gachi (On The Value of Seokdok Kugyol in the History of Korean Language), Kugyol Studies, 3, 1-28.

Kobayashi, Y. (2002). Hanguk-ui Gakpiljeomto-wa Ilbon-ui Kohunjeom-ui Gwangye (A Study on Gakpiljeomto in Korea and The Old Kunten in Japan), Kugyol Studies, 8, 21-76.

Kobayashi, Y. (2003). Silla Gyeongjeon-e Giipdoen Gakpil Munja-wa Buho - Kyoto·Otani Daehakjang Pan-bi-lyang-loneseoui Balgyeon (Charcters and Marks recorded in Silla Buddhist Sutra Pan-bi-lyang-lon of Kyoto-Otani University), Kugyol Studies, 10, 5-30.

Lee, S. (2001). On the Symbol-Kugyol (符號口訣) noted on a text of Huayanjing (華嚴經), Kugyol Studies, 7, 1-32.

Lee S. (2003). On Korean Versions of Surangama-sutra (首楞嚴經), Kugyol Studies, 11, 153188.

Lee S. (2004). Some remarks on Gakpil (角筆) Bujeom-Kugyol (符點口訣), Kugyol Studies, $13,289-316$.

Lee S. et al. (2005). Gakpil kugyeol-ui Haedok-gwa Beonyeok 1 - Chojodaejanggyeong-ui $<$ Yugasajiron> Kwon 5.8eul Jungsimeuro- (Dicipherment and Translation of Cipher Kugyols 1-foucused on <Yugasajiron> vol. 5.8 in Chojodaejanggyeong ). Seoul, Korea: Taehaksa.

Lee, S. et al. (2006a). Gakpil kugyeol-ui Haedokgwa Beonyeok 2 - Jubon Hwaeomgyeong Kwon Je 36 - (Dicipherment and Translation of Cipher Kugyols 2 - <Jubon Hwaeomgyeong > vol. 36 ). Seoul, Korea: Taehaksa.

Lee, S. et al. (2006b). Gakpil kugyeol-ui Haedokgwa Beonyeok 3 - Jubon Hwaeomgyeong Kwon Je 6, 57 (The Dicipherment and Translation of Cipher Kugyols 3 - <Jubon Hwaeomgyeong > vol. 6, 57 ). Seoul, Korea: Taehaksa.

Lee, Y. (2003). On Function of Negative Markers in Seokdok-Kugyol (釋讀口訣) Texts of Koryo dynasty period, Kugyol Studies, 11, 153-188.

Lee, Y. (2004). The Present Condition of Studies on Cipher Kugyol, Hanguk munhwa, 33, Seoul National University Kyujanggak Institute for Korean Studies.

Lee, Y. (2010). Grammatical Negation in Jeomto Seokdok Kugyol Texts of the Koryo period, Kugyol Studies, 24, 97-131.

Nam, P. (2000). Koryosidae-ui Jeomto kugyeol-e daehayeo (A Study on Jeomto kugyol in Koryo period ), Seojihakbo, 24, Hangukseojihakhoe, 5-45.

Nam, P. (2002a). Sillasidae Kugyol-ui Jaegu-reul Wihayeo (A Study for Reconstruction of Kugyol in Silla period), Kugyol Studies, 8, 77-93.

Nam, P. (2002b). Koryosidae Gakpiljeomto Seokdok kugyeol-ui Jongnyu-wa geu HaedokJinbonhwaeomgyeong Kwon 20-ui Jeomto seokdok Kugyol-eul Jungsimeuro (Several 
Kinds of Gakpiljeomto Seokdok Kugyeol Texts and Their Decipherment on Jinbonhwaeomgyeong vol 20), Joseonhakbo, 183, Joseonhakhoe, 1-22.

Park, J. (2003). Interpretation of Mark Gugyeols Written in Zhouben ${ }^{『}$ Huayan jing』 volume 36 - With Special Interest in Correspondence with Character Gugyeols, Kugyol Studies, $11,211-248$.

Park, J. (2004). Duplication of Cipher Kugyols on the Same Position and Various Marks in Zhouben (周本) 《Huayanjing (華嚴經)》 volume 6, Kugyol Studies, 13, 129-148.

Park, J. (2006). Interpretation of Cipher Kugyols Written in Jinben 《Huayanjing》 volume 20, Kugyol Studies, 16, 173-209. 
